\title{
Eastern Enlargement of the EU: a Topsy-Turvy Endgame or Permanent Disillusionment
}

\author{
Miroslav N. Jovanović \\ UN Economic Commission for Europe
}

\begin{abstract}
The Treaty of Nice (2001) strongly protects the interests of the current 15 European Union member countries. The new voting structure in the enlarged European Union preserves the existing members blocking influence over new policies. In addition, there is a cap on the Unions total expenditure. It is on these terms that the European Union is ready to enlarge eastwards. Eight countries with economies in transition (the Czech Republic, Estonia, Hungary, Latvia, Lithuania, Poland, Slovakia and Slovenia) and two market economies (Cyprus and Malta) are due to join the European Union in 2004. Bulgaria and Romania may follow, but not before 2007. The final operational entry conditions set by the European Councils in Brussels and in Copenhagen (2002) are such that this enlargement may be relatively cheap for the European Union in financial terms, but much costlier and slower for the accession countries than expected by politicians, both in the European Union and in the accession countries. The reasons for this include the self-imposed limits on European Union expenditure and the increasingly stringent standards that come from the ever-growing acquis communautaire that are costly to introduce, implement and enforce, but enlargement will take place for political reasons.
\end{abstract}

\footnotetext{
${ }^{1}$ Un ringraziamento particolare va a Marina Rossi per il suo valido contributo, mai richiesto ma sempre presente. I have benefited from discussions with many friends and colleagues, but I owe special gratitude to Victoria Curzon Price, as well as to Lisa Borgatti, Eckhard Freyer, Maurice Guyader, Jong Eun Lee, Marinette Payot, Martin Pontzen, Franco Praussello and Pia Weber. Statistical material from Eurostat was kindly supplied by Jarko Pasanen and Wayne Codd. James Wiltshire kindly edited the text and provided a number of valuable suggestions. An earlier version of this article was published in the Economia Internazionale in 2000.

The views expressed are my own and do not reflect the position of the organisation for which I work. *Corresponding address: UN ECE, Transport Division, Palais des Nations, 1211 Geneva 10, Switzerland, Tel: +41-22-917 2493 Fax: +41-22-917 0039 E-mail: miroslav.jovanovic@unece.org. (C2004-Center for International Economics, Sejong Institution, All Rights Reserved.
} 
- JEL Classification: F15

- Key words: accession countries, enlargement, acquis communautaire, funds, competition, European Council

\section{Introduction}

The objective of this article is to contribute to the ongoing discussion about the enlargement of the European Union (EU). Eight countries with economies in transition, the Czech Republic, Estonia, Hungary, Latvia, Lithuania, Poland, Slovakia and Slovenia, and two market economies, Cyprus and Malta, concluded ${ }^{2}$ terms for full membership with the EU from May 2004. Bulgaria and Romania may join the EU in 2007. Turkey is mentioned and referred to in this article only as a potential candidate for entry negotiations. ${ }^{3}$

This article begins by looking at the strategic priorities of the EU. It then examines the economic structure of the accession countries. Entry criteria and the costs and benefits of EU enlargement are analysed in separate sections. This is followed by certain reflections about the disillusionment on both sides of the story regarding the imminent enlargement. The conclusion is that the final operational entry conditions set by the European Council in Brussels (2002) are such that this enlargement may be relatively cheap for the European Union in financial terms, but much costlier and slower for the accession countries than expected by politicians, both in the European Union and in the accession countries. The reasons for this include the voting rules in the enlarged EU, self imposed limits for the EUs

\footnotetext{
${ }^{2}$ The Treaty of Accession was signed in Athens on 16 April 2003.

${ }^{3}$ Although it has never been the public position of the EU, there are influential voices that reflect serious privately expressed anxiety of many officials that the EU is storing up trouble by embracing Turkey. The worry is that if Turkey enters the EU, then the biggest EU country could be South-east European. For example, a prominent Christian Democrat in the European Parliament, Wilfried Martens, said that, The EU is in the process of building a civilisation in which Turkey has no place. In addition, eminent Dutch politicians have expressed doubts about the Turkish application because there are too many of them, and they are too poor - and they are Muslims (The Economist, 15 March 1997, p. 31). Or, Valéry Giscard dEstaing, Chairman of the Convention on the Future of Europe, said that Turkeys membership would represent the end of the European Union... Those who are pushing hardest for the enlargement in the direction of Turkey are adversaries of the EU' (The Financial Times, 8 November 2002). The European Council in Copenhagen (2002) decided that it would decide in December 2004 if Turkey fulfils conditions for the start of entry negotiations. However, a former senior American official declared that 'the US has done everything but slap the German government across the face in an effort to get the EU to agree to Turkish membership' (The Financial Times, 2 February 2003).
} 
expenditure and increasing standards that come from the ever-growing acquis communautaire $^{4}$ that are costly to introduce, implement and enforce. Nonetheless enlargement will take place for political reasons. The central and east European accession countries will need to invest lots of effort, time and funds of their own to comply with the requirements for full membership.

\section{Priorities of the European Union}

The European Union is at an important turning point. On the international political front, it was unable to solve the neighbouring problem in the former Yugoslav region and it is not faring any better in the Middle East. In the economic field it is not capable of creating new jobs and reducing unemployment. The Economic and Monetary Union (EMU) was the Unions major project during the 1990s. Following that, the EU member countries are trying hard to stick to tough macroeconomic criteria prescribed by the letter of the Maastricht Treaty and the Stability and Growth Pact. At the same time, there is a declared political determination to enlarge the EU.

In order to face all those challenges, the EU is trying to change. However, it is not yet entirely known what shape the new EU will take in the future. Following the second Irish referendum in 2002, the Treaty of Nice (2001) has been duly ratified. Although this Treaty is presented as an act that permits the new EU enlargement (which is true), the EU 15 member countries preserved their blocking influence over the introduction of any new policy in the new voting structure (which is even more true). This is particularly valid for the existing large member countries. As far as the Convention on the Future of Europe is concerned, its results are considered by an inter-governmental conference that is supposed to finalise the European Constitution before 2004. It is possible that the EU may change and eventually improve beyond recognition. The stakes are therefore quite high.

At present, the EU has five general strategic priorities:

- The creation of the Single European Market was the objective for the 1985-92

\footnotetext{
${ }^{4}$ The existence and operation of the EU is based on law. The whole body of the established EU laws, policies and practices are called the acquis communautaire or the EU patrimony. It is widely estimated that the acquis consisted of around 80,000 pages of legal acts in 2003. The ever evolving and expanding acquis was enlarged by 2,341 new regulations in 2002 alone. However, most of the regulations have limited time duration.
} 
period. Following that, ongoing goals include making rules more transparent and effective, as well as removing the remaining and potentially new market distortions. These areas include competition, taxation, telecommunications, company statute and the environment in order to continuously deliver the full benefits of the Single European Market to the citizens.

- Safeguard of the EMU and the euro.

- Institutional (European Constitution) and policy reforms (agriculture, regions).

- If all goes well with the previous four goals, enlargement of the EU will be a priority during the first decade(s) of the new century.

- Following the attack on the World Trade Centre in New York on 11 September 2001, security gained additional importance.

\section{Economic Structure of the Accession Countries}

The 12 accession countries would bring 106 million additional consumers into the EU. If Turkey is included, then this number would increase to 174 million. Some of those countries are so small that the EU economy would hardly register their entry. As for the level of development measured by GDP per capita in purchasing power standard (PPS), accession countries are at a far lower level of development than the EU average (Table 1). However, there are four distinct

Table 1. GDP per capita at purchasing power standard and population in the EU, accession countries and Turkey in 2001

\begin{tabular}{lcc}
\hline \multicolumn{1}{c}{ Country } & GDP per capita,PPS & Population in million \\
\hline EU(15) & 23,160 & 380.5 \\
Cyprus & 18,460 & 0.7 \\
Slovenia & 15,970 & 2.0 \\
Czech Republic & 13,280 & 10.3 \\
Malta & 11,900 & 0.4 \\
Hungary & 11,880 & 10.2 \\
Slovakia & 10,780 & 5.4 \\
Estonia & 9,820 & 1.4 \\
Poland & 9,210 & 38.6 \\
Lithuania & 8,730 & 3.5 \\
Latvia & 7,710 & 2.4 \\
Bulgaria & 6,510 & 7.9 \\
Romania & 5,860 & 22.4 \\
Turkey & 5,210 & 68.6 \\
\hline
\end{tabular}

Source: Eurostat (2003). 
groups of newcomers. Cyprus and Slovenia are in the group of relatively developed accession countries. In descending order, the other groups consist of the Czech Republic, Malta, Hungary and Slovakia (with GDP of roughly a half of EU average); then come Estonia, Poland, Lithuania and Latvia. Bulgaria, Romania and Turkey (with a quarter of EU average GDP) are in the bottom group. If there were no changes in the EU policy, most of the accession countries would be eligible for a large share of EU regional funds. This is particularly relevant for Poland and Romania because of their large population and relative backwardness measured by the GDP per capita. However, the European Council in Brussels (2002) confirmed earlier budgetary restrictions and put new limits on EU expenditure.

The economic structure of the accession countries shows that services are the predominant economic sector (Table 2). The same is true for the EU. However, there are concerns regarding agriculture. The contribution of this sector to the GDP in the accession countries is much higher than is the case in the EU. In Bulgaria and Romania, for example, it is 6.5 and 7 times, respectively, the EU average.

The unemployment problem in the accession countries is uneven (Table 3). Bulgaria, Poland and Slovakia had unemployment rates that are more than twice as high as the EU average in 2002. The problem is that these are relatively large

Table 2. Structure of GDP in the EU, accession countries and Turkey in 2001 (per cent)

\begin{tabular}{lccc}
\hline & \multicolumn{3}{c}{ Structure of GDP in $\%$} \\
\cline { 2 - 4 } Country & Agriculture $^{\mathrm{a}}$ & Manufacturing $^{\mathrm{b}}$ & Services $^{\circ}$ \\
EU & 2.1 & 22.3 & 75.6 \\
Bulgaria & 13.8 & 23.0 & 63.2 \\
Cyprus & 4.2 & 13.3 & 82.5 \\
Czech Republic & 4.2 & 32.8 & 63.0 \\
Estonia & 5.8 & 22.7 & 71.5 \\
Hungary & 4.2 & 28.3 & 67.5 \\
Latvia & 4.7 & 18.7 & 76.6 \\
Lithuania & 7.0 & 28.3 & 64.7 \\
Malta & 2.4 & 24.5 & 73.1 \\
Poland & 3.4 & 25.4 & 71.2 \\
Romania & 14.6 & 28.5 & 56.9 \\
Slovakia & 4.6 & 27.5 & 67.9 \\
Slovenia & 3.1 & 31.0 & 65.9 \\
Turkey & 12.1 & 23.8 & 64.1 \\
\hline
\end{tabular}

Source: Eurostat (2003).

${ }^{a}$ Agriculture, hunting, forestry and fishing.

${ }^{b}$ Excluding construction. 
Table 3. Unemployment rate (2002) and share of agriculture in total employment (2001) in the EU, accession countries and Turkey \%

\begin{tabular}{lrr}
\hline \multirow{2}{*}{ Country } & Unemployment rate & Agriculture in total employment \\
\cline { 2 - 3 } & 2002 & 2001 \\
\hline EU & 7.6 & 4.3 \\
Bulgaria & 16.3 & 26.7 \\
Cyprus & 3.3 & 4.9 \\
Czech Republic & 9.8 & 4.6 \\
Estonia & 6.8 & 7.1 \\
Hungary & 8.0 & 6.1 \\
Latvia & 7.6 & 15.1 \\
Lithuania & 10.9 & 16.5 \\
Malta & 5.5 & 2.2 \\
Poland & 18.1 & 19.2 \\
Romania & 8.1 & 44.4 \\
Slovakia & 17.5 & 6.3 \\
Slovenia & 11.8 & 9.9 \\
Turkey & 10.4 & 35.4 \\
\hline
\end{tabular}

Source: UNECE (2003); Eurostat (2003); European Commission (2003).

economies in the group of newcomers. As for the sectoral structure of employment, 45 per cent of the Romanian labour force is employed in agriculture. This is largely semi-subsistence farming and its share is more than 10 times the EU average. Almost a fifth of the labour force in Poland is in agriculture (this is more than four times the EU average). 19 per cent of Poland's labour employed in agriculture contributes little more than 3 per cent to the GDP. This compares with figures of 4 and 2 per cent, respectively, in the EU(15). If farm labour in Poland migrates to cities, this may increase the productivity of Polish farming. However, if there are no new jobs in manufacturing and services sectors to absorb such an inflow, significant societal tensions may develop.

A relatively active labour market policy (safety regulation) which is the feature of the economies in the EU countries may harm the accession countries in the short term. Nobody questions the social and other features of high labour protection standards, but these standards are often expensive to implement and maintain. This may provide hindrance to the creation of new firms, as well as protection of existing marginal jobs. The general EU labour market rigidities may slow down the painful and ongoing transition and adjustment processes in the accession countries. 


\section{Entry Criteria}

'Any European state may apply to become a Member of the Union' (Article O of the Maastricht Treaty). ${ }^{5}$ That is the only Maastricht Treaty based (necessary) condition for a country to be considered for full membership of the EU. In addition, there are several other sufficient, economic and political requirements for entry. These were formally defined during the European Council in Copenhagen (1993). The potential candidate country must fulfil three conditions. It must have a functioning market economy, a democratic political system and accept, implement and enforce the acquis communautaire.

First, apart from the Czech Republic and Slovakia, not a single transition country had a fully functioning market economy even before they became centrally planned countries (van Brabant, 1996). Entry into the EU, in particular an early entry by transition economies, could cause a serious external shock. Their economies are not yet fully adjusted to the market-based economic system and their manufacturing and services sectors are still too fragile to absorb the expensive acquis communautaire. Early entry into the EU without full macroeconomic stabilisation and modernisation of the output structure may be painful for them. Countries that pass through the transition phase would not be able to withstand the strict rules governing competition with EU producers in most industries. ${ }^{6}$ Transition fatigue is already apparent in these countries and is evidenced by the return of the recycled communists to office.

The second condition is that the prospective entrant has a stable democratic political system. This means a multi-party parliament; rule of law and respect for human and minority rights. It also includes good neighbourly relations and no territorial disputes. With regard to the last criterion, not a single transition country passes the test, and the northern part of Cyprus is still occupied. Nor do certain EU countries fare well here: just consider Northern Ireland. However, the advantage is that they are already in the EU.

\footnotetext{
${ }^{5}$ The unresolved question is what is a European state? Are those the ones that are the members of the UN Economic Commission for Europe (include among others the United States, Canada, Turkmenistan and Uzbekistan)? Does religion matter? Is a European state the one that is a member of the Council of Europe?

${ }^{66}$ Several commissioners, led by Frits Bolkenstein, who is responsible for the internal market, said many of the candidate countries would not be ready to withstand the pressures of competition once they joined' (The Financial Times, 10 October 2002, p.1).
} 
The European Union is interested in resolving pressing problems in the region. There are some signs that the prospect of EU membership may ease tensions, as happened with Hungary and Romania in 1996, Greece and Turkey in 2000 or Serbia and Montenegro with Croatia in 2003. The EU needs to assist accession countries in order to create a peaceful and prosperous neighbourhood for itself in the future. The question has not been whether central and east European countries need to be incorporated into the EU. The question has always been the cost to the EU(15) of expanding their club, as well as how much time the enlargement may take?

The third condition relates to the acquis communautaire or the Community patrimony (the whole body of the established EU laws, policies and practices). The accession countries must accept, implement and enforce the existing set of rules. The belief that skilful national diplomacy and bargaining may provide better deals for the accession countries is false. Entry to the EU is just the beginning, not the end of the story regarding competition. The only possibility for negotiations concerned the length of the adjustment period and, potentially, the size of funds that may help to implement it. Agenda 2000 (1997), the EU's plan for action in the medium term, is clear on this point. The new EU member countries are required to apply, implement and enforce the acquis communautaire upon accession. In order to safeguard the EU internal competition rules, those measures that relate to the Single European Market should be applied immediately upon accession. ${ }^{8}$ However, there may be certain transition measures for a limited period of time. Many EU companies are against any transition period that may be given to their competitors from the accession countries because they fear social and environmental dumping from the east.

The fourth, tacit, requirement is that an enlargement should not imperil the EUs financial resources, nor should widening of the EU risk deepening of the integration process. If there were no changes in the EU policies and if accession

\footnotetext{
${ }^{7}$ The EUs acquis communautaire is a clear demand for harmonisation. The Treaty of Westphalia (1648) ended the Thirty Years War. The Treaty established the principle that the states are free to do whatever they like within their own borders (for example, choice of religion). However, only those measures that have external implications concern foreigners. This was strongly undermined by the NATO attack on Yugoslavia in 1999 or the US-led war with Iraq in 2003 which were not authorised by the UN. No similar attacks were undertaken against Turkey (Kurds, Cyprus), China (Tibet), Russia (Chechnya) or in certain parts of the Middle East.
}

${ }^{8}$ European Commission (1997), p. 52; Bulletin Quotidien Europe, 12 November 2001. 
countries entered the unreformed EU, various early estimates stated that the annual transfers from the EU to those countries would cost the EU budget around _50 billion a year. ${ }^{9}$ That is about half of the entire current annual budget for EU(15). The European Council in Brussels (2002) set the final operational financial rules that made eastern enlargement of the EU relatively cheap for the EU as will be seen below.

All the necessary conditions for entry into the EU reveal that the Union has very high discretionary powers and flexibility to select would-be members, as well as to set the time, pace and conditions of entry.

\section{Costs and Benefits}

\section{A. Accession countries}

Accession countries from central and eastern Europe share political, security and economic reasons for joining the EU. Politically, these countries have a still young and potentially fragile democratic system. Fragility comes from unfulfilled grand hopes that the change for the better towards a market-type democratic system can take place in a relatively short period of time and at a relatively acceptable cost. Although the immediate threat of an armed conflict in Europe is not highly likely (even though there are spots such as the Balkan peninsula, the Aegean Sea, Cyprus), there is still an apprehension regarding the division of "spheres of influence' between the West and Russia. The central, eastern European and Baltic States only recently obtained their freedom from the 'eastern bloc'. They have concerns both about preserving their independence from the East and about 'losing' that independence to the West.

With regard to the economic issues, there are important gains for the accession countries from entry of the EU:

- The major benefit for the accession countries is secure access to the huge EU market. This is particularly relevant for the goods that are politically 'sensitive' for the EU (agricultural products, textile, steel, chemicals), as the accession countries have comparative advantage in the production of those goods. Entry would mean a kind of 'insurance policy' that the EU trade regime would credibly remain open for their exports.

- The second gain would be the possibility for labour migration into the rest of

${ }^{9}$ An early short survey of select studies is given by Baldwin (1995). 
the EU following the specified adjustment period. This may, however, have a two-edged effect. If the educated and the experienced leave the accession countries, the productivity in the 'accession region' would suffer and funds for the education of experts would be lost. A relatively tight labour market in the rest of EU(15) would however prevent such a scenario occurring. In addition, experience has shown that labour migration (wars apart) takes place chiefly when labour cannot find employment in its country of origin.

- A third benefit from entry includes access to the structural and other EU funds. This would all give an impetus to strengthen the market system (van Brabant, 1996).

\section{Structural aid and the geography of production}

None of the potential gains from entry to the EU are without risks. In some cases, the costs are quite serious. Central and east European countries still have fragile economies that would be exposed to the chill wind of fierce competition in the Single European Market. Adjustment troubles are well-known even for relatively advanced transition economies, as evidenced by the problems experienced in the former East Germany after the Anschluss of 1989. Gross annual transfers from the western part of the reunified Germany to the east were around DM 180 billion ( $€ 90$ billion) during the 1990s (Table 4). Such massive aid to the former East Germany will be necessary for at least another five years in order to try to adjust its economy and catch up with the rest of the country. If the eastern part of the reunited Germany needs such massive annual transfers of around 4 per cent of west German GDP, ${ }^{10}$ one shudders to think about the volume of potential transfers that will be needed by other accession countries. ${ }^{11}$

There have been certain positive results during this 'catch up' process as exemplified in the doubling of productivity (Table 5). However, the financial cost was immense. The question remains as to whether such massive aid will be

\footnotetext{
${ }^{10}$ Economic Commission for Europe (2003), p. 37.

${ }^{11}$ If the rules on regional aid from EU were not changed, then such of aid to the accession transition countries would transfer resources that are equal to 10-20 per cent of the new members GDP. That is far more than 3.5 per cent of GDP that Greece received in 1996 (The Economist, 3 August 1996, p. 28). Agenda 2000 limited the level of annual structural and cohesion aid to 4 per cent of the recipient countrys GDP (European Commission [1997], p. 25). This was reconfirmed by the European Council in Berlin (1999) in $\S 46$. Given the relatively small size of the economies of the accession countries, this rule would tightly limit the amount they could get from the EU.
} 
Table 4. Annual public financial transfers ${ }^{\mathrm{a}}$ from western to the eastern part of Germany 1991-99 in billion DM

\begin{tabular}{cccccccccc}
\hline Transfer & 1991 & 1992 & 1993 & 1994 & 1995 & 1996 & 1997 & $1998^{\mathrm{b}}$ & $1999^{\mathrm{c}}$ \\
\hline Gross & 139 & 152 & 168 & 168 & 185 & 187 & 183 & 189 & 194 \\
Net & 106 & 115 & 129 & 125 & 140 & 140 & 136 & 141 & 144 \\
\hline
\end{tabular}

Source: Herausgeber BMI, Jahresbericht der Bundesregierung zum Stand der Deutschen Einheit. Berlin, 1998.

Data for 1998 and $1999=$ Bundestags-Drucksache 13/11472, p. 11 .

ancluding social insurance.

bartly estimated.

${ }^{\mathrm{c}}$ According to the draft budget.

Table 5. Convergence indicators for East Germany 1991, 1996 and 1998 (West Germany=100)

\begin{tabular}{lccc}
\hline \multicolumn{1}{c}{ Indicator } & 1991 & 1996 & 2000 \\
\hline Average monthly wages & & & \\
$\quad$ Gross & 48.3 & 76.7 & $77.2^{*}$ \\
$\quad$ Net & 54.8 & 84.2 & $86.1^{*}$ \\
Productivity & & & \\
$\quad$ Total economy & 34.3 & 66.8 & 68.2 \\
$\quad$ Manufacturing & 23.9 & 63.6 & 69.5 \\
$\quad$ Construction & 48.8 & 75.7 & 67.8 \\
GDP per capita at current prices & 32.8 & 54.0 & 59.9 \\
\hline
\end{tabular}

Source: Economic Commission for Europe (1997). Economic Survey for Europe in 1996-1997. New York: United Nations, p. 30.

Wirtschaftsdaten neue Bundesländer, Bundesministerium für Wirtschaft und Technologie. Berlin, 2001. *1998

necessary in the medium and long term. Aid may kill local incentives to adjust and it may create a structurally dependent economy out of the former East Germany as happened with the Italian Mezzogiorno. Welfare has been raised in the former East Germany and, consequently, wages have increased above productivity. Similarly, the Italian social system prevented wages from falling to competitive levels in the Mezzogiorno. As a result, both southern Italy and the former East Germany have high unemployment and dependency on public transfers.

Bearing all these issues in mind, one may ask if the accession countries are not, perhaps, aspiring to do too much too soon? One does not know where the funds to accommodate the adjustment of the accession countries might come from. The Maastricht criteria for the EMU and the Stability and Growth Pact require budgetary cuts throughout the EU. The European Council in Cannes (1995) 
allocated 'only' $€ 6.7$ billion to the Phare Programme for the period 1995-99. Therefore, most of the funds will have to come from the accession countries themselves or from foreign loans.

As for the period 2000-06, there is a decision to keep spending limit for all EU activities at the current level of 1.27 per cent of the total GDP of the 15 member countries. This limit is combined with strict constraints on the national public expenditure that are related to the EMU. However, Agenda 2000 earmarked $€ 45$ billion for the period 2000-06 (a kind of mini Marshall Plan) to be used as preaccession aid to the accession countries. During that time, accession countries will be granted $€ 1$ billion a year as structural aid plus $€ 0.5$ billion a year for agricultural development. ${ }^{12}$ Future negotiations about the financing of EU(25) expenditure (Financial Perspective 2007-13) will be much more difficult than was the case in the past. The EU(15), in particular the Eurozone member governments will argue against an expansion of the EU budget at a time when they are making unprecedented efforts at home to cut spending in order to keep within the rules of the EMU.

In theory, economic integration may, but will not necessarily bring greater benefits to the regions/countries that lag behind the centre of economic activity in their development. However, if production linkages (forward and backward) are strong and internal to an industry such as in chemicals or financial services, and if imperfect competition prevails, economic integration would trigger agglomeration tendencies. If those linkages are not limited to a relatively narrow industry group, but are strong across industries and sectors, integration would produce agglomeration tendencies in select spots. If labour is not mobile, the whole process would tend to open up new and widen the existing regional wage differentials (Venables, 1996). Although this may produce deindustrialisation tendencies in the peripheral regions, it does not mean that integration is not desirable. For instance, education and regional policies increased the attractiveness of Spain, Finland or Ireland as locations for various manufacturing industries, as discovered by EU and foreign investors.

As for the structure of industrial geography of production in the EU and relying on the study by Midelfart-Knarvik et al. (2000, pp. 46-7), the observation is that the EU countries became more specialised from the early 1980s than was previously the case. This confirms the theoretical expectations of standard, neo-

\footnotetext{
${ }^{12}$ European Commission (1997), pp. 25 and 53.
} 
classical and new theories of economic integration. A new pattern of industrial production is emerging in the EU. The major features of this divergence process in the geography of industrial production in the EU are that this process is slow and does not provoke great adjustment costs; the most remarkable change in the geography of production was the spreading of relatively high technology and high skill industries towards the EU periphery (Ireland and Finland); and that the availability of highly skilled and educated workers is becoming an increasingly important determinant for industrial location.

\section{Acquis communautaire}

Economic transition towards a market-type system is in itself a lengthy and costly process. Furthermore, to accept and to implement a continuously evolving acquis communautaire is costly not only for the new members, but also for the countries that are already in the EU. Being less developed, the accession countries have both a lower financial, technical and administrative capacity, and require a greater degree of reform to incorporate and digest the EU rules. Many things are highly regulated in the EU. They include not only health, environment and consumer protection, but also safety at work and social standards. Many of those items do not directly increase productivity. To make matters worse, more and tougher rules are on the horizon. With an out-of-date capital stock, there is a dilemma in the accession countries. Should they invest scarce capital first into upgrading output potential or do something else or both (in what proportion) $?^{13}$

The cyanide spill in Romania (2000) was the worst ecological disaster since the Chernobyl nuclear accident (1986). It reminded everyone about the gravity of the problem in the accession countries. ${ }^{14}$ The environmental dimension of the acquis communautaire has 320 pieces of green legislation. To implement all those laws

\footnotetext{
${ }^{13}$ The NATO entry, done with little public debate, may harden both the economic adjustment and the EU accession. Most of the investment in the military forces is not producing direct value added which can be consumed or exported. Investment in this sector crowds out investment in other, market oriented sectors because of the need to coordinate and to harmonise with other NATO partners and standards. Hungary, for example, met less than a third of its NATO commitments three years after the NATO entry in 1999. If Hungary is considered to be a successful country in transition, then one may question the ability of Bulgaria and Romania to meet the NATO challenge (The Times, 18 November 2002). If this continues, the Americans would control the still fragile democracies in the new member countries; guide political, military and other types of European integration; and be even closer to the oil rich Caspian and Middle Eastern regions.
}

${ }^{14}$ Agenda 2000 states that the environment is a major challenge for enlargement (European Commission [1997] p. 49). 
could cost the 10 transition accession countries as much as $€ 110$ billion over a decade. ${ }^{15}$ Table 6 provides information on a part of these harmonisation costs that deal with water, air and waste standards in six selected accession countries. The EU would offer some financial support to these countries in order to ease the burden of meeting the entry criteria, but most of the funds would have to come from the new member countries themselves. ${ }^{16}$ Can these costs be compensated for by the potential benefits that would come from the entry? If so, how can one measure that? How long would it take? Is such an investment justified at this moment? Public opinion polls in transition countries rank concern for the environment much lower than health care, education, security and the economy.

All these data reveal that a number of accession countries are not only worse off than current EU members by a considerable degree, but they still constitute a distinct structural class by themselves. The difference in income per capita, as well as investment needed to comply with the acquis communautaire between the accession countries and that of the EU(15) is not only structural, but also huge.

The benefit side of these investments is hard to measure and is unfortunately often forgotten. Safe water free of toxins or pollutants, pure air and secure handling of waste would contribute both to an improvement in quality of life and savings in

Table 6. What would cost six accession countries have to do to reach the EU environmental standards?

\begin{tabular}{lrrccc}
\hline \multirow{2}{*}{ Country } & Water & Air & $\begin{array}{c}\text { Waste } \\
\text { (maximum) }\end{array}$ & $\begin{array}{c}\text { Total investment } \\
\text { (maximum) }\end{array}$ & $\begin{array}{c}\text { Total } € \\
\text { per capita }\end{array}$ \\
\cline { 2 - 5 } Poland & 18.1 & 13.9 & 3.3 & 35.2 & 927 \\
Hungary & 6.6 & 2.7 & 4.4 & 13.7 & 1,306 \\
Czech R. & 3.3 & 6.4 & 3.8 & 12.4 & 1,427 \\
Slovakia & 1.9 & 1.9 & 1.6 & 5.4 & 760 \\
Estonia & 1.5 & n.a. & n.a. & 1.5 & n.a. \\
Slovenia & n.a. & 0.7 & 1.1 & 1.8 & n.a. \\
\hline
\end{tabular}

Source: Parlement européen, La politique de l'environnement et l'élargissement, Fiche thématique no. 17, Luxembourg, 23 March 1998, p. 15.

\footnotetext{
${ }^{15}$ European Voice, 28 May 2003, p. 14.

${ }^{16}$ Compliance with those standards refers to all member countries of the EU. For example, the privatised British water industry is expected to spend around $\$ 60$ billion between 1989 and 2004 to bring its water supply network into line with EU directives (The Financial Times, 6 October 1997, p. 18).
} 
resources. For example, it is estimated that by cutting air pollution, all accession countries could avoid between 43,000 and 180,000 cases of chronic bronchitis and between 15,000 and 34,000 cases of premature deaths. The cumulative value of these benefits to the accession countries until 2020 is estimated to be in the range of $€ 134-681$ billion. $^{17}$

Even though the European Commission noted in its annual Enlargement Reports (2002) that accession countries have made meaningful progress in the adjustment of their economies in relation to the EU(15), serious flaws still persist. They include weaknesses in administrative capacity, ${ }^{18}$ under-performing judicial systems and public-sector internal auditing and widespread corruption. However, even the EU's administrative capacity is far from perfect. For the eight year in a row, the EU Court of Auditors was able to certify the legality and regularity of only 5 per cent of the EU expenditure (mainly relating to internal administration). The rest, i.e. 95 per cent, was not given a positive statement of assurance owing to the found incidence of errors. ${ }^{19}$

\section{Economic and monetary union}

The theory of international monetary integration is based on criteria which include factor mobility, openness of the economy, similar rates of unemployment, diversification of the economic structure, coordination of economic policies and comparable rates of inflation between the integrating countries (Jovanović, 1998, pp. 170-185). The Maastricht Treaty brought conditions for the EMU that are not known in the theory of monetary integration. A sceptic might say that this is the reason why the EMU may work! In any case, if transaction costs remain significant and if there is a danger that comes from the exchange risk, then the EMU might give stability and an additional impetus to the expansion of intra-EU trade.

The Maastricht criteria for the EMU are the following:

- a high degree of price stability (low inflation),

- a sound public finance position (budget deficit of maximum 3 per cent of the GDP),

\footnotetext{
${ }^{17}$ Uniting Europe, 10 December 2001.

${ }^{18}$ This may be one of the consequences of the sadly underpaid officials in the public sector.

${ }^{19}$ The Financial Times, 6 November 2002.
} 
- national debt of less than 60 per cent of GDP,

- no devaluation within the exchange rate mechanism for at least two preceding years and

- the national interest rate needs to be within the 2 per cent margin of the three best performing countries.

These criteria may create some barriers for accession to the EU. Agenda 2000 and subsequent documents state that each accession country is required to apply, implement and enforce the acquis communautaire upon accession. In order to safeguard the EU competition rules, those measures that relate to the Single European Market should be applied immediately upon accession. ${ }^{20}$ Being out of the EMU, a new member country's currency may be the target for a speculative attack on the currency market that the country may not be able to withstand. ${ }^{21}$ The country may alter the rate of exchange. By doing so, trade flows and free competition in the Single European Market could be jeopardised. Hence the need for the accession countries to join the EMU. The three EU member countries that are currently out of the EMU should not be taken as best precedents for the accession countries. The 'three' are already fully adjusted EU members with stable and developed economies. It would potentially be tough to manage the EU economy when one half of the EU uses the euro while the other half does not.

If the macroeconomic situation remains stable in the future, many accession countries may not have great difficulty in satisfying most (inflation apart) of the loosely interpreted Maastricht criteria for the EMU (Tables 7 to 10, respectively). ${ }^{22}$ All accession countries have growing economies which is a very positive development. The problem is to maintain this positive differential growth rate over and (well) above the EU rate for a long period of time in order to catch up with the EU level of development. A relatively stable catch up process with the EU may well require a rate of inflation that may be over and above the norms required by the EMU. This is a very real conflict between the demand for an accelerated growth and the EMU request for the stability both in prices and in the exchange rate. Long

\footnotetext{
${ }^{20}$ European Commission (1997), p. 52.

${ }^{21}$ When the Polish government presented its 2004 budget ( $€ 9.9$ billion deficit) to parliament, the Polish zloty hit its lowest level ever against the euro (The Financial Times, 30 September 2003).

${ }^{22}$ Some of the Maastricht criteria were loosely interpreted as national debt was over 120 per cent of the GDP in 1997 both in Belgium and in Italy, but both countries were permitted in 1998 to enter the EMU from the start, even though the Maastricht norm is 60 per cent.
} 
Table 7. Government deficit(-)/surplus(+) in the EU, accession countries and Turkey 19972004 (\% of GDP)

\begin{tabular}{lrrrrrrrr}
\hline \multicolumn{1}{c}{ Country } & 1997 & 1998 & 1999 & 2000 & 2001 & 2002 & $2003^{*}$ & $2004^{*}$ \\
\hline EU & -2.4 & -1.6 & -1.3 & 2.0 & -1.6 & -2.2 & -2.5 & -2.4 \\
Bulgaria & -0.3 & 1.3 & 0.2 & -0.6 & 1.7 & -0.7 & -0.6 & -0.5 \\
Cyprus & -5.3 & -5.6 & -5.0 & -2.7 & -3.0 & -3.5 & -4.0 & -3.5 \\
Czech Republic & -2.7 & -4.5 & -3.2 & -3.3 & -5.5 & -6.5 & -6.3 & -5.9 \\
Estonia & 2.0 & -0.4 & -4.0 & -0.4 & 0.2 & 1.3 & -0.5 & -0.6 \\
Hungary & -6.8 & -8.0 & -5.3 & -3.0 & -4.1 & -9.1 & -4.9 & -3.7 \\
Latvia & -0.2 & -0.7 & -5.3 & -2.7 & -1.6 & -2.5 & -2.9 & -2.6 \\
Lithuania & -1.1 & -3.1 & -5.6 & -2.7 & -1.9 & -1.8 & -1.9 & -2.0 \\
Malta & -10.7 & -10.8 & -8.3 & -7.0 & -7.0 & -6.1 & -5.2 & -4.1 \\
Poland & -4.3 & -2.3 & -1.5 & -1.8 & -3.9 & -4.2 & -4.2 & -4.0 \\
Romania & -4.5 & -3.2 & -4.5 & -4.5 & -3.4 & -2.6 & -2.7 & -2.7 \\
Slovakia & -5.5 & -4.7 & -6.4 & -12.8 & -5.6 & -7.7 & -5.3 & -3.8 \\
Slovenia & -1.9 & -2.3 & -2.2 & -3.2 & -2.5 & -1.8 & -1.5 & -1.2 \\
Turkey ${ }^{*}$ & -13.0 & -12.0 & -19.0 & -6.0 & -29.0 & -13.7 & -9.8 & -6.9 \\
\hline
\end{tabular}

Source: Eurostat (2003) and European Economy (2003).

*Estimates and projections

Table 8. National debt in the EU, accession countries and Turkey 1997-2004 (\% of GDP)

\begin{tabular}{lrrrrrrrc}
\hline & \multicolumn{8}{c}{ National debt } \\
Country & 1997 & 1998 & 1999 & 2000 & 2001 & 2002 & $2003^{*}$ & $2004^{*}$ \\
\hline EU & 71.0 & 68.8 & 67.7 & 63.8 & 63.1 & 62.7 & 63.5 & 63.2 \\
Bulgaria & 105.1 & 79.6 & 79.3 & 73.6 & 66.4 & 53.0 & 52.0 &.. \\
Cyprus & 57.7 & 60.1 & 56.8 & 54.6 & 55.6 & 58.6 & 61.2 &.. \\
Czech Republic & 13.0 & 13.7 & 14.5 & 16.6 & 23.3 & 27.1 & 29.6 &.. \\
Estonia & 6.9 & 6.0 & 6.5 & 5.1 & 4.8 & 5.8 & 5.5 &.. \\
Hungary & 64.2 & 61.9 & 61.2 & 55.5 & 53.4 & 56.3 & 56.8 &.. \\
Latvia & 12.0 & 10.6 & 13.7 & 13.9 & 15.7 & 15.2 & 19.2 &.. \\
Lithuania & 15.7 & 17.1 & 23.4 & 24.3 & 23.4 & 22.7 & 22.9 &.. \\
Malta & 51.5 & 64.9 & 60.8 & 61.3 & 66.1 & 66.4 & 66.9 &.. \\
Poland & 46.9 & 41.6 & 42.7 & 37.2 & 37.3 & 41.8 & 43.3 &.. \\
Romania & 16.5 & 18.0 & 24.0 & 23.9 & 23.1 & 22.7 & 23.7 &.. \\
Slovakia & 28.8 & 28.9 & 43.8 & 46.9 & 48.1 & 42.6 & 41.8 &.. \\
Slovenia & 23.2 & 25.1 & 26.4 & 27.6 & 27.5 & 28.3 & 27.8 &.. \\
Turkey* & 53.0 & 50.0 & 67.4 & 57.6 & 105.4 & 95.0 & 86.3 &.. \\
\hline Soury
\end{tabular}

Source: Eurostat (2003) and European Economy (2003).

"Estimates and projections 
Eastern Enlargement of the EU: a Topsy-Turvy Endgame or Permanent Disillusionment 847

Table 9. Growth rate of GDP in the EU, in accession countries and Turkey in 1997-2004 (\% change over preceding year)

\begin{tabular}{lrrrrrrrr}
\hline & \multicolumn{7}{c}{ Growth rate } \\
\cline { 2 - 8 } \multicolumn{1}{c}{ Country } & 1997 & 1998 & 1999 & 2000 & 2001 & 2002 & $2003^{*}$ & $2004^{*}$ \\
\hline EU & 2.5 & 2.9 & 2.8 & 3.4 & 1.6 & 0.9 & 1.3 & 2.4 \\
Bulgaria & -5.6 & 4.0 & 2.3 & 5.4 & 4.0 & 4.0 & 4.5 & 5.0 \\
Cyprus & 2.4 & 5.0 & 4.5 & 5.1 & 4.1 & 1.8 & 2.0 & 3.8 \\
Czech Republic & -0.8 & -1.0 & 0.5 & 3.2 & 3.6 & 3.6 & 2.8 & 3.9 \\
Estonia & 9.8 & 4.6 & -0.6 & 7.1 & 5.0 & 3.5 & 4.9 & 5.1 \\
Hungary & 4.6 & 4.9 & 4.1 & 5.2 & 3.8 & 3.5 & 3.7 & 4.1 \\
Latvia & 8.4 & 4.8 & 2.8 & 6.8 & 7.7 & 5.0 & 5.5 & 6.0 \\
Lithuania & 7.3 & 5.1 & -3.9 & 3.8 & 5.9 & 4.0 & 4.5 & 5.0 \\
Malta & 4.8 & 3.4 & 4.0 & 5.5 & -0.8 & 2.5 & 3.1 & 3.7 \\
Poland & 6.8 & 4.8 & 4.0 & 4.0 & 1.1 & 1.4 & 2.5 & 3.7 \\
Romania & -6.0 & -4.8 & -1.1 & 1.8 & 5.2 & 4.5 & 4.9 & 5.0 \\
Slovakia & 5.6 & 4.0 & 1.3 & 2.2 & 3.3 & 3.6 & 3.7 & 4.5 \\
Slovenia & 4.6 & 3.8 & 5.2 & 4.6 & 3.0 & 3.0 & 3.4 & 3.7 \\
Turkey & 7.5 & 3.0 & -4.7 & 7.4 & -7.4 & 3.7 & 3.7 & 4.5 \\
\hline
\end{tabular}

Source: UNECE (2003); Eurostat (2003) and European Economy (2003).

*Estimates and projections

Table 10. Annual rate of inflation in the EU, accession countries and Turkey in 1997-2004 $(\%)$

\begin{tabular}{lrrrrrrrr}
\hline & \multicolumn{7}{c}{ Annual rate of inflation } \\
\cline { 2 - 8 } Country & 1997 & 1998 & 1999 & 2000 & 2001 & 2002 & $2003^{*}$ & $2004^{*}$ \\
\hline EU & 2.1 & 1.8 & 1.3 & 2.5 & 2.6 & 2.2 & 2.1 & 1.7 \\
Bulgaria & $1,082.6$ & 18.7 & 2.6 & 10.3 & 7.4 & 5.8 & 4.5 & 4.0 \\
Cyprus & 3.3 & 2.3 & 1.1 & 4.9 & 2.0 & 2.8 & 4.3 & 2.2 \\
Czech Republic & 8.0 & 9.7 & 1.8 & 3.9 & 4.5 & 1.8 & 1.5 & 2.8 \\
Estonia & 9.3 & 8.8 & 3.1 & 3.9 & 5.6 & 3.5 & 3.5 & 4.0 \\
Hungary & 18.5 & 14.2 & 10.0 & 10.0 & 9.1 & 5.4 & 5.0 & 4.5 \\
Latvia & 8.1 & 4.3 & 2.1 & 2.6 & 2.5 & 1.9 & 2.5 & 3.0 \\
Lithuania & 8.8 & 5.0 & 0.7 & 0.9 & 1.3 & 0.4 & 1.0 & 2.5 \\
Malta & 2.6 & 2.3 & 2.3 & 3.1 & 3.0 & 2.5 & 2.7 & 2.4 \\
Poland & 15.0 & 11.8 & 7.2 & 10.1 & 5.3 & 1.9 & 1.1 & 2.3 \\
Romania & 154.9 & 59.1 & 45.8 & 45.7 & 34.5 & 22.5 & 16.0 & 11.8 \\
Slovakia & 6.1 & 6.7 & 10.5 & 12.0 & 7.3 & 3.3 & 8.8 & 7.4 \\
Slovenia & 8.3 & 7.9 & 6.1 & 8.9 & 8.6 & 7.6 & 6.0 & 5.5 \\
Turkey & 85.7 & 84.6 & 64.9 & 54.9 & 54.4 & 45.0 & 25.9 & 18.0 \\
\hline
\end{tabular}

Source: UNECE(2003); Eurostat(2003) and European Economy (2003).

"Estimates and projections 
run growth projections predict that it may take around 30 years (one generation) for most of the central and eastern European countries to catch up with the income levels in low income EU countries (Table 11). ${ }^{23}$ With average income per capita about half the EU average, central and east European countries need continuous economic growth. For them this may be a much more important sign of economic success than an early Eurozone entry.

Monetary policy in the accession countries may gain in general credibility and stability inside the EMU, but different growth priorities and asymmetric shocks relative to other Eurozone countries may introduce tensions within the EMU. While the Eurozone may serve the interest of many of the 12 participating member countries fairly well, this may not be the case for an EMU of perhaps 27 member countries. This difficulty is compounded with the Governing Councils voting system in which each participating country has one vote. A reduction in the weight of small countries in the decision making process may be necessary in the future (de Grauwe, 2002).

Table 11. Period needed to reach $75 \%$ of the EU(15) average GDP per capita

\begin{tabular}{lccc}
\hline \multicolumn{1}{c}{ Country } & $\begin{array}{c}\text { Assumption } \\
\text { From 2004 }\end{array}$ & $\begin{array}{c}\text { Average achieved } \\
\text { 1995-2002 }\end{array}$ & $\begin{array}{c}\text { Period needed to } \\
\text { reach 75\% of EU GDP } \\
\text { per capita in years }\end{array}$ \\
\hline Bulgaria & 5.0 & 0.5 & 40 \\
Cyprus & 3.8 & 3.6 & 1 \\
Czech Republic & 3.9 & 1.7 & 19 \\
Estonia & 5.1 & 4.9 & 23 \\
Hungary & 4.1 & 3.9 & 24 \\
Latvia & 6.0 & 5.6 & 24 \\
Lithuania & 5.0 & 3.9 & 28 \\
Malta & 3.7 & 3.3 & 25 \\
Poland & 3.7 & 3.9 & 50 \\
Romania & 5.0 & 0.4 & 44 \\
Slovakia & 4.5 & 3.7 & 22 \\
Slovenia & 3.7 & 3.9 & 7 \\
Turkey & 4.5 & 2.9 & 61 \\
\hline Source: Eup & & &
\end{tabular}

Source: European Economy, Occasional Papers No. 4, July 2003, p. 10.

\footnotetext{
${ }^{23}$ Also Fisher, Sahay and Végh, 1998, p. 28; Economic Commission for Europe, 2002, p. 183.
} 


\section{Agriculture}

Farm gate prices in the accession countries were on the average within a range of 40 to 80 per cent of the EU level which is guaranteed by the Common Agricultural Policy (CAP). ${ }^{24}$ If the unreformed CAP prices were to apply directly in the accession countries, that would give a strong boost to output of both crop (cereals, oilseeds and sugar) and livestock production, as well as milk. At the same time, an increase in the price of farm goods in the accession countries could provoke social tensions. These price hikes would hit social groups such as the retired and the unemployed hard, unless their income situation is improved. However, it would be difficult to convince the accession countries not to increase farm production, unless they can see clear signs that the CAP is undergoing reform prior to their entry. One thing was clear: enlargement of the EU could not easily proceed without a prior change in the CAP. A deep reform of the CAP would test the actual seriousness of the EU about enlargement.

The eastern enlargement would also introduce a practical problem on how to operate country-specific transitional arrangements. If, for example, alignment of the prices of agricultural products between the EU and Hungary takes place at a different rate from alignment of prices in Poland, it would be necessary to impose tariffs, not only between the accession countries and EU(15), but also between the accession countries themselves.

Introduced in the 1960s, the CAP was an instrument for ensuring security in food supplies and a means for the protection of income of farmers. As food shortages were eliminated, as the EU started to dispose of surpluses of agricultural output and as farmers income were safeguarded on the average against unfavourable developments, the EU concern shifted towards food safety and protection of the environment. This last concern is of great importance, as the accession countries have a legacy of serious environmental damage.

Reform of the CAP represents one of the most serious challenges for the EU. It would have consequences both for the EU internal operation, for external economic relations and for enlargement. A reform plan, proposed in mid-2002, would break the link between intervention and production. Farm subsidies would be linked to rural conservation. In addition, export subsidies would be significantly reduced. However, this idea to reform the CAP was put off by France (with Germanys support) for 2006 when the new Financial Perspective (2007-13) is to be

\footnotetext{
${ }^{24}$ European Economy, 1997a, p. 8.
} 
negotiated. In addition, Britain, Germany, the Netherlands and Sweden are particularly concerned about the future farm spending. These countries would like to see a certain reform of the CAP before the EU offers potentially generous subsidies to farmers in the accession countries. This is important as the EU(15) has around 7 million farmers, while central and east European countries would bring additional 3.8 million. ${ }^{25}$ The lobbying and voting power of farmers in the enlarged EU would increase in theory, but in practice it may be difficult to organise them because of their different interests and priorities. In any case, enlargement without a reform of the CAP would not be affordable for the EU.

France and Germany were the driving force behind the European Council in Brussels (24-25 October 2002) deal that brought the adjustment (limit) of the future CAP payments in the light of the forthcoming enlargement. From 2006 total CAP subsidies would have a ceiling. This would keep payments static at current levels during the period 2007-13 with a possibility to have a light inflation-proof increase of 1 per cent per year. In real terms, these payments would almost certainly decline steadily. Subsidies to farmers in new member countries would be limited to only 25 per cent of those paid to farmers in the EU(15) in 2004. However, the payments to farmers would be gradually brought into parity by 2013. EU farmers would lose from this deal over the coming decade, and this would hit this influential French lobby hard. Therefore, France has made a significant enlargement-related concession. Farmers in the new member countries would lose their illusions about hefty subsidies from Brussels, but most others would gain: in particular, EU consumers and potential exporters to the EU.

\section{B. European Union}

The European Union is generally interested in enlargement for various political, security, ecological and economic reasons. Key EU values would be secured in countries that ardently want them. What, however, the accession countries would actually contribute to the EU's economy is less easy to discern. One negative organisational aspect of the enlargement process is that the EU may become cumbersome and ungovernable. The enlarged EU may turn out into an extended free trade area. In addition, the entry of 13 accession countries (including Turkey)

\footnotetext{
${ }^{25}$ The rural working age population in Poland is growing annually by 100,000 . To create alternative jobs for many existing and newly arriving farmers may be like pushing water uphill (The Financial Times, 10 June 2003).
} 
would increase the EU population by 46 per cent, while the volume of the EUs GDP would enlarge only 7 per cent at current prices and 15 per cent at PPS (Table 12) which is roughly comparable to the Dutch GDP.

Is the 'eastern' market, with relatively cheap labour and certain possibilities for investment, ${ }^{26}$ an opportunity or a threat for the EU? Germany and Austria fear that eastern enlargement would set off an annual inflow of more than 300,000 immigrants (OECD, 2003, p. 85). This would amount to over 3 million over a decade. Workers from the accession countries will have a preference in the EU labour market over others that come from non-EU countries. However, there is a five-year long transition period, which may be extended for another two years, before these workers gain full liberty to work anywhere in the EU. When Spain and Portugal

Table 12. Total GDP at current prices and in purchasing power standard in the EU, candidate countries and Turkey in 2001

\begin{tabular}{lrc}
\hline & $€$ billion & $€$ billion PPS \\
\hline Country & & \\
Bulgaria & 15.2 & 51.8 \\
Cyprus & 10.2 & 12.5 \\
Czech Republic & 63.3 & 126.2 \\
Estonia & 6.2 & 13.4 \\
Hungary & 58.0 & 121.0 \\
Latvia & 5.5 & 18.2 \\
Lithuania & 13.4 & 30.5 \\
Malta & 4.0 &.. \\
Poland & 196.7 & 355.9 \\
Romania & 44.4 & 131.3 \\
Slovakia & 22.3 & 58.0 \\
Slovenia & 20.9 & 31.8 \\
Turkey & 164.6 & 357.3 \\
13 Candidate countries & 627.7 & $1,317.8$ \\
EU(15) & $8,814.8$ & $8,814.8$ \\
\% of EU(15) & 7.1 & 15.0 \\
\hline
\end{tabular}

Source: Eurostat (2003).

\footnotetext{
${ }^{26}$ Central Europe received $\$ 16.3$ billion in foreign direct investment in 2001 . The primary beneficiary was Poland ( $\$ 7$ billion), the Czech Republic ( $\$ 5$ billion) and Hungary ( $\$ 2.4$ billion) (Economic Commission for Europe, 2003, p. 93). While relatively low wages could have been an advantage for the central and east European countries in the past, they are becoming less and less so. For example, real wages in Hungary are on a rise. This may be one of the reasons why Hungary could easily experience a net capital outflow of foreign investment in 2003. Investors are leaving for China.
} 
entered the EU they had a seven-year long transition period before the full labour mobility was granted. However, when labour mobility became fully free, there was no large labour migration flow to the rest of the EU partner countries.

The potential economic and political gains for the EU need to be combined with at least two potential economic costs that are often mentioned.

- The first is the need to finance the adjustment of the accession countries to the acquis communautaire and to the Maastricht criteria for the EMU. ${ }^{27}$ In a situation with serious austerity measures in the EU countries, the question is, where the funds would come from? The European Council in Brussels (2002) put a cap on all EU expenditure in order to make enlargement cheap for the EU in financial terms.

- The second 'cost'(?) could come from the (potential) loss of jobs and business in the sensitive manufacturing industries and in agriculture in the EU because of the penetration of goods from the east. There may be strong lobby pressure on policy makers is certain countries to slow down eastern enlargement and/or request compensations from the EU. This second cost may be exaggerated. As a result of the signing of Europe Agreements, sensitive manufactured goods from the accession countries already enter the EU mainly free of tariff and quantitative restrictions.

The production structure in the accession countries within each of the three broad economic sectors is very different from the prevailing structure in the existing EU (15). If the gains from trade depend on the extent of these differences, the (private) gains should be correspondingly large. Hence, a surge of 'sensitive' imports from the accession countries by the EU may be welcome. The job losses in the sensitive sectors will be more than made-up for by expansion in the non-sensitive sectors. ${ }^{28}$ This approach is hotly disputed by politicians and well entrenched lobbies, but if

\footnotetext{
${ }^{27}$ The total direct expenditure of the EU on Enlargement in the period 1990-2006 is estimated to be $€ 69.5$ billion (Uniting Europe, 14 July 2003, p. 7). In relative terms and over the period of 17 years this cost does not seem to be large at all compared with the EU GDP.

${ }^{28}$ With around 14.5 million EU(15) citizens out of work in 2003, the sensitivity of the issue in the EU does not come as a surprise. A similar debate on trade liberalisation with Mexico and the creation of the North American Free Trade Agreement (NAFTA) was going on in the United States in the early 1990s. In spite of strong opposition by the US presidential candidate Ross Perot regarding the free trade agreement between the US and Mexico and a possible loss of jobs in the American economy ('giant sucking sound' of jobs moving south [The Economist, 18 September 1993, p. 51.]), only 117,000 Americans have applied for the benefits offered to workers displaced by the free trade agreement. If compared with the 1.5 million who lose their jobs each year from factory closures, slack demand and corporate restructuring (The Economist, 5 July 1997, p. 17), the cost of adjustment to the agreement by the US does not seem too high. Free trade with Mexico might have destroyed some jobs in the American textile industry which is labour intensive, but it created new ones in electronics, aeronautics or writing software.
} 
economists have only one thing to say about adjustment 'costs', then this is it.

In the medium term southern EU countries need not fear the eastern enlargement of the EU and the potential 'exodus' of jobs to central and eastern Europe because of lower wages there. If there is no adjustment pain for these southern countries, there may also be little 'gain' from enlargement. If firms were looking only for low-cost production locations, then China and India may be superior long-term choices than countries in central and eastern Europe. If relatively low wages were the only determining factor for the location of production, then the EU would have already been flooded with cheap goods from those countries. Factors such as productivity, the capital stock, size and growth of the market and stability often play a more decisive role for investors than mere differences in nominal wages. But this may change in the future in the accession countries. For example, PeugeotCitroën announced in 2003 that it intends to invest and to locate a large (€700 million) car assembly factory in Slovakia. The factory would start production of around 300,000 small cars in 2006. The management intends to be closer to fast growing markets in accession countries and to profit from wage rates that are a fifth of the rates paid in the EU(15) for similar operations. Earlier plants established by western companies in central and eastern Europe were often only additions to their plants that exist in the west. This one will serve as a replacement plant. ${ }^{29}$ Even though similar stories to this one may be repeated in the region, this 'eastern region' is still too small to impact significantly on total production and real income elsewhere in the EU.

The most important argument about the employment impact of the eastern enlargement of EU has, unfortunately, not yet made its way into the public consciousness. It also put certain academic debates on the wrong foot. The eastern enlargement may create certain new jobs or at least keep the existing higher quality jobs in the EU. Isolated and highly publicised stories about the closure of a firm due to the enlargement are not typical for the whole EU economy. Those stories need to be seen in the context of a bigger picture. Because of the start of the EMU in the majority of EU countries, the average unemployment rate over the coming years will be to a large extent at the level chosen by the European Central Bank. The Bank may pay little or no regard to the situation in the EU trade balance with the accession countries. This is important if one keeps in mind that the total annual merchandise trade of the accession countries with the EU(15) in recent years is

\footnotetext{
${ }^{29}$ The Financial Times, 15 January 2003.
} 
twice as much as the EU(15) trade with Switzerland alone.

Spain, France and Austria (with tacit support from a number of other countries) were cautious about the enlargement of the EU. Spain has two national fears that can be substantiated. First, there may be an inflow of cheap fruits and vegetables from the east in EU(15) which would put Spains market share for these goods at risk. Second, expenditure from generous structural funds would be directed eastwards to the detriment of the beneficiaries in Spain. Following the EU enlargement, Spain will cease to qualify for much of the relatively generous EU regional aid that it currently receives. Indeed, Spain may become even a net contributor to the EU budget. Therefore, it has a vested interest in keeping EU expenditure under strict control. France has reservations about the overall capacity (among other things) of the accession countries to take all the obligations that are required for the EU membership.

\section{Disillusionment}

The European Union as we know it now is finished. However, what will come out of the European Constitution and, in particular, its ratification may not be known for several years. If the form-book is a reliable guide regarding the European Constitution, then the outcome will be decided, when France and Germany and perhaps another larger EU country reach an agreement during the very last minutes of negotiations and horse trading, and then pull others into the deal. ${ }^{30}$

The key procedure in the EU has been that all member countries try to move together or not at all (one-size-fits-all). ${ }^{31}$ That is not always easy to apply even among the current 15 member states. It does not seem to be operationally feasible in an enlarged EU. So, would flexibility make the enlarged EU of almost 30 countries more manageable ? $^{32}$ Would flexibility, i.e. a multi-speed organisation of the EU, make it more viable? Would it strengthen the EU or make it looser?

\footnotetext{
${ }^{30}$ Recall that certain EU countries have to (Ireland) or want to (France) put the new European Constitution on a referendum. This is a much less certain approval procedure than the vote in the national parliament.

${ }^{31}$ One-size-fits-all policies in Europe may become increasingly inappropriate in a highly diversified Europe. This may wreck individuality. The Irish and Danish demonstrated that clearly when given a referendum on certain matters.

${ }^{32}$ Imagine how simple it would be for 25 councillors to decide where to go, for example, for a dinner. And then, imagine the ease with which they may decide about monetary or any other policy.
} 
The Treaty of Nice is popularly portrayed as the act that allowed the new EU enlargement. However, the EU 15 member countries first preserved their influence in the new voting structure. After enlargement, however, that will change substantially. The EU voting allotments and procedures will change drastically as a result of the Treaty of Nice. There will be soon a triple-test:

- Smaller states (most of the accession countries are small) will have proportionally more voting power than larger ones. Post-enlargement, a Poland-led eastern bloc of 10 countries would have the largest voting weight.

- If a new policy is to be adopted, then it must have the support of a majority of member states. The East(10) would need only three votes from any of the EU(15) to push through new policies.

- The final requirement is the 'killer': new policies must have the support of states that represent 62 per cent of the EU's expanded population of 451 million. ${ }^{33}$ The East(10) combined have only 16 per cent. Hence, while the East(10) certainly can play a major part in setting or blocking the agenda, it can not necessarily force anything through. Neither can anyone else.

This all puts the EU on track for a train wreck as far as quick action is concerned. No bloc, indeed no two blocs, would be able to force through any policy, but nearly any single bloc would have the ability to veto any policy. And there is no shortage of topics that would face harsh clashes of interest. Hence, one may predict that the basic (economic) policy structure of the EU would remain as it is.

This dimension is internationally important as the EU countries, in contrast to the United States (US), have faith in a social contract. This was obvious in the attitude towards the Kyoto Protocol on Global Warming (1997) or the International Criminal Court (2002). The EU can exert the only substantial international pressure towards such ends, particularly as the US appears as a rogue state on those issues. If the EU falls down in dysfunctional paralysis because of enlargement, everyone may turn poorer and may suffer. On foreign policy issues, for example Iraq, EU countries are more unwilling than ever to speak with one voice. In fact, only Britain and France have strong international clout as they sit on the UN Security Council. However, neither speaks for the EU in this forum. If past enlargements can give some indication, it may take a generation before the change is absorbed and before there is a functional coordination throughout the EU. If this proves to be the case, then this is great news for the US.

\footnotetext{
${ }^{33}$ Bulgaria and Romania are not included. Even if they were, this would not alter the general picture.
} 
Consideration of the issues of the timing and terms of the new EU enlargement has been highly speculative. Entry depends on the political will (and the funds) of the EU countries. However, the funds and the political will existed even when Spain and Portugal were negotiating entry with the EU during the 1980s, but their entry took several years more than expected and almost an additional decade to get to full speed with the rest of EU. In addition, the Iberian enlargement of the EU was technically and economically much simpler than the accession of central and east European transition countries.

When the EU last accepted 'poor countries' (Spain and Portugal in 1986), the European Community, as it was then called, was not a single market for goods, services, capital and labour. The EU deepened integration and the EMU was introduced in 1999. Even though Spain and Portugal were 'poor' countries, they were market economies. With this in mind, the chances of even the most advanced central and east European countries of accepting, implementing and enforcing the acquis communautaire in full seem bleak for quite some time in the future.

The European Union has few incentives and limited funds to accept countries with economic structures that are significantly different from its own. Such an attitude may seem hypocritical since the West has spent almost half a century encouraging those countries to join the free market and democratic world. Accession countries also need to exercise patience. Jovanovic (1997a, p. 368) argued that if all goes well from the vantage point of 1997, meaning to finalise smoothly entry negotiations including ratification in all involved countries and a post-entry adjustment period of around a decade, it would take the most advanced central and east European countries some 15-20 years to become full members of the EU.

A clear message to accession countries came from the top of the European Commissions Directorate General for Enlargement in 2000. ${ }^{34}$ These countries should not attach too much importance to the date of accession, but rather to the essential issue: quality of the accession, i.e. the respect of the accession criteria. To set at that time a firm date for the entry might be a mistake. This might lock the EU in a promise it might regret. The enlargement should take place in such a way as to be beneficial both to the existing EU member countries and to the central and east European countries. In addition, the EU has to remain strong after enlargement. The European Commission would recommend access only if the accession country can respect rights and duties from the first day of accession. ${ }^{35}$ Such clear and open

\footnotetext{
${ }^{34}$ Bulletin Quotidien Europe, 15 March 2000.
} 
messages contributed to a drop in the enthusiasm among the accession countries for a fast entry. The Convention on the Future of Europe (2002-03) on the institutional reform of the EU raised new doubts among the central and east European countries. These countries feared that the accession would be made subject to new conditions or that something is being plotted against them. Expectation fatigue is taking its toll. Nonetheless, the European Commission considered that Cyprus, the Czech Republic, Estonia, Hungary, Latvia, Lithuania, Malta, Poland, Slovakia and Slovenia would be ready for EU membership from May 2004. Bulgaria and Romania have as their indicative date for accession 2007 (European Commission, 2002, p. 33-4).

Can the relative economic and development success of Ireland be repeated by the accession countries? One has to keep in mind that Ireland is a relatively small country (population 3.7 million). Its story resembles the stories of Singapore or Hong Kong. Ireland created a business-friendly environment for new technology firms and foreign direct investment. A relatively small amount of foreign investment could have a powerful impact on a small economy such as Ireland. In addition, over a long period, Ireland unlike Greece, used EU funds for infrastructure projects of lasting value. Greece, on the other hand, lagged behind other EU countries for years following its EU entry. There is a serious concern that with Poland on board, the EU may load itself with a much larger version of Greece for years to come.

A near absence of public debate in the EU about enlargement leaves most people in ignorance about the tectonic political and economic changes that this involves. For most people this is a remote abstraction and a done deal. Enlargement should not be done behind peoples back as was the case with the EMU. That is an important reason for the Irish rejection of the Treaty of Nice in 2001. This can easily serve many as an argument that the enlargement process is going too fast and that public opinion is not supporting it. Ireland was the only EU country to offer the privilege to its citizens and to consult them directly on the Treaty, the rest, i.e. 99 per cent, of the EU citizens were deprived of such possibility to express them directly on this crucial issue.

The disillusionment problem regarding European integration is perhaps due less to the fact that the elite decides the shape, extent and direction of European

\footnotetext{
${ }^{35}$ Bulletin Quotidien Europe, 29 March 2000; 12 November 2001
} 
integration. The problem is much more in the fact that this elite disdains ${ }^{36}$ voters and does not try hard enough to explain and convince the electorate that European integration is a favourable and promising affair for everyone in the long term. There is an obvious distrust by a noteworthy part of the electorate of a distant, alienated and unaccountable elite that imposes rules. If this elite occasionally asks the people in a referendum about certain crucial national decisions regarding European integration, the elite may simply run as many referendums on the same issue as prove necessary until it gets the outcome it desires in order to have a democratic sugar-coating for the already taken decision. The European and national elites have to work very hard indeed to win the hearts, minds and confidence of the people for further projects in European integration.

The European Council in Copenhagen (12-13 December 2002) and previously in Brussels $(2002)^{37}$ reonfirmed its Berlin (1999) ${ }^{38}$ decision that the ceiling for enlargement related expenditure set out for the years 2004-06 must be respected. That is to say that total EU expenditure must fit into own resources that are limited to 1.27 per cent of the combined EU GDP of all member countries. Therefore, the EU has very little room for manoeuvre in which to enlarge its funds. During the three-year, from 2004 to 2006', of the $€ 25.1$ billion in payments for the period, $€ 14.1$ billion will be covered by new member states contributions, so that the net cost for the EU15 would be $€ 10.3$ billion' (Enlargement Weekly, 28 January 2003). Consequently, the actual annual net 'cost' of the eastern enlargement will be $€ 3.4$ billion (or less than $€ 10$ per current EU citizen). ${ }^{39}$ From 2006 there will be very tough negotiations and horse trading in order to define the new Financial Perspective for the period 2007-13. If one recalls the CAP adjustment deal, full equality of the accession countries with the rest of the EU(15) will not come before 2013. Before that, the new member countries will in certain respects be secondclass citizens. In any case, the EU will enter a much more difficult phase of integration in 2006 than most people imagine.

The fact that public transfers to agriculture, and on regional policy grounds, are

\footnotetext{
${ }^{36}$ Do you still recall the ratification of the Treaty of Nice and the enthusiasm about the introduction of the euro?

${ }^{37}$ European Council, Brussels 2002, Presidency Conclusions, $§ 10$.

${ }^{38}$ European Council, Berlin 1999, Presidency Conclusions, $§ 16$ and Table B.

${ }^{39}$ The 'net benefit' for Spain, for instance in 2001, amounted to $€ 7.7$ billion or $€ 192$ per EU citizen (Uniting Europe, 23 December 2002, p. 6).
} 
to be limited is surely a good thing. Aid has never helped anyone in the medium and long term. The central and east European countries need private investment, not public aid. Many would argue that public investment is a good thing. If devoted to infrastructural public goods, it can be. But a lot gets lost on the way. The administrative capacity of public officials in the central and east European countries to handle projects in a new way still needs to be strengthened. ${ }^{40}$ There are fears that a lot of EU aid goes to the general budget, allowing local ex-communists to pursue policies for which there is little or weak democratic support and accountability, as well as to prop up lame-duck firms, rather than to assist promising projects which only require assistance in their initial phase.

The European Council in Brussels (2002) brought two safeguard clauses; one regarding the internal market and the other in the area of justice and home affairs, of up to three years duration after accession. These measures may be invoked even before accession and the "duration of such measures may extend beyond the threeyear period'. ${ }^{41}$ Hence, the message from this European Council to the accession countries was: warm welcome to our club. But from today we are watching you closely applying and enforcing' our' rules. Any mistake and you will pay for that. And do not forget, your dreams about big money from our kitty will remain just that. Dreams. What an unfriendly message regarding investment, particularly private investment, in and towards the accession countries! If there is a' mishap', an introduction of EU safeguards may easily jeopardise returns on an investment.

The European Union is becoming a more and more awkward institution to be in. The Union finds ways to interfere directly not only in the composition of democratically elected governments of member states, but also in the leadership of individual national parties. Democracy is in certain cases reduced to a simple acceptance of others decisions (recall the Irish referendum regarding the Treaty of Nice). The normal democratic principle of separation of power (legislation-execution-jurisdiction) does not exist in a clear way within the appointed European Commission. This contributed to a lousy administration and corruption that led to the resignation of the European Commission in 1998. Many people question the wisdom of surrendering additional sovereign rights to a supranational administration. The community

\footnotetext{
${ }^{40}$ The European Commission confirmed in July 2003 that some of the $€ 22$ billion allocated to accession countries for the period 2004-06 may remain unused unless adequate administrative structures are set up quickly (Enlargement Weekly, 22 July 2003).
}

${ }^{41}$ European Council, Brussels 2002, Presidency Conclusions, $§ 8$. 
method in the decision making process in which the European Commission leads in the EU affairs is being silently, but forcefully replaced by an inter-governmental method in which the principal EU moving force is agreement among EU member governments. Following this type of inter-governmental accord, the European Commission is left to trail behind. In any case, the Commission does not have any more personalities and leaders to compare with Walter Hallstein and Jacques Delors.

There are various alliances within the EU. The principal Franco-German (at times including the Low Countries) alliance is somehow weakened by the other alliances, however they still do not have always strong economic and political muscle within the EU. Nonetheless, the Scandinavian countries harmonise their posture, Spain and Portugal often act together, while Britain allies with anyone that wants to slow down the process of integration. A possible eastern EU tier of a group of countries with similar histories and goals may add an important new factor that may contribute to the watering down of the leading Franco-German integration axis. This may slow down the entire integration process. This is just what Britain wanted in the post-Second World War period from outside the EU and what it did from within it after the entry in 1971. Britain, basically, wants to be present in the heart of EU decision making process, but without being over-committed in order to have a generous room for own manoeuvres. To put it bluntly: France and Germany make unhedged bets on Europe, while Britain has always been hedging them.

Another great piece of news for the US is that the EU (bar Britain) thought that it would be accepting new member countries that would have a 'European' view on international events. As a gesture of good will, the European Council in Copenhagen (2002) created an additional special 'cash-flow facility' for the year 2004 and for budgetary compensation for the years 2004-06. ${ }^{42}$ The Polish benefit out of this additional subsidy that would go directly into the Polish budget will be $€ 1$ billion. ${ }^{43}$ At about the same time, Poland announced that it would purchase US built F-16 fighter jets ( $\$ 3.5$ billion), rather then EU made Gripens or Mirages. ${ }^{44}$ In addition, and much to the irritation of France, the central and east European countries openly sided with the US in the crises over Iraq (2003). The EU is deeply split on such a crucial foreign policy issue. Having in mind the easy blockage of

\footnotetext{
${ }^{42}$ European Council, Copenhagen 2002, Presidency Conclusions, Annex I.

${ }^{43}$ Bulletin Quotidien Europe, 15 December 2002.

${ }^{44}$ The Financial Times, 27 January 2003.
} 
any new initiative in the enlarged EU, there are questions about the way forward. Is it to start again from the beginning? Should the original core of France and Germany with the Benelux be re-created?

\section{Conclusion}

European integration can be divided into nine groups of countries that move at different speeds:

- The first and fastest group includes the 12 EU countries that take part in the Eurozone.

- Even within the first group there is a subgroup which includes big countries (France, Germany and Italy) that are able to sway the European Commission their own way. This has happened in 2002 when the European Commission postponed a deadline for the EMU countries to balance their budgets from 2004 to 2006. This is the reason why smaller EU countries want a strong European Commission that would be their friend and protector against the will of big countries.

- The third set of three EU countries includes the ones that do not participate in the Eurozone (Britain, Denmark and Sweden).

- The fourth circle consists of the EU countries members of the Schengen agreement.

- A fifth group contains ten central and east European countries, as well as Cyprus and Malta which join the EU in 2004.

- Bulgaria and Romania are slow speed accession countries which have a tentative EU entry date in 2007.

- Switzerland, Iceland and Norway are all separate cases.

- "Turkey only has the title of a accession country (see Annex)".

- Other European countries, mainly in the Balkans and east of Poland and Romania compose the ninth group.

European integration has always been based on the political decision to secure peace and liberty in Europe. That is the purpose of the EU, although many observers have forgotten it. European integration is intended to mitigate the impact of old rivalries and replace them by mutual economic advantage and social prosperity. The eastern enlargement will not bring the EU extra efficiency or growth, nor will it create new jobs. Its basic objective is to give a certain support to friendly countries and governments in their reform and general stabilisation 
process.

The Treaty of Nice changed the voting system in the enlarged EU. It makes the introduction of new policies and fast reaction to new challenges very slow and difficult, while it makes the blocking of new initiatives relatively swift and easy. In addition, the EU limited its total expenditure in advance of enlargement. Some welcome the eastern enlargement as they consider that this will water down the EU into an extended free trade area. Others are depressed because they think that enlargement is being done in rush, without adequately prepared candidates and without a duly consolidated EU. The cost of implementing the acquis communautaire is staggering, and this represents one good reason why the central and east European countries should think again. A very long transition period might be the only reasonable alternative solution, but it may be to late for such thoughts now. ${ }^{45}$

When full integration with the EU was first discussed at the beginning of the 1990s and when it was a remote possibility, everyone was enthusiastic about it. The more the date of entry approaches, the more this enthusiasm evaporates and certain serious doubts emerge. The EU is about to carry out its promise that many now wish had never been made. The general mood is one of worry, rather than of cheer. Even though there is currently no great support in the public opinion for enlargement neither in the accession countries (in spite of positive referendums on the accession), nor in the EU member states, enlargement is taking place anyway. That is the political will of those that have the power to decide.

European integration has always been in the hands of national elites. This is why the treaties on which European integration is based are complicated and incomprehensible to the man in the street. ${ }^{46}$ When the national elites decide to defend Europe from various challenges, in particular external ones (coming from both west and south), public enthusiasm to deepen and to enlarge the EU may regain momentum. The major priority for the national elites in the EU countries must now be to reclaim popular backing for the process of European integration. Therefore, the forthcoming enlargement of the EU and the European Constitution deserve support, but perhaps the speed of these changes is not so important as mistakes could be paid with a longer-term loss of confidence in European integration.

\footnotetext{
${ }^{45} \mathrm{Can}$ you imagine the European Court of Justice having to deal with all those cases of social and environmental dumping?

${ }^{46}$ If European integration is such a profound and a necessary process, can one explain why Europe consisted of 32 countries in 1990, while it now has 48 ?
} 
Festina lente! (Hurry, slowly!)

The issue of Turkish aspiratons for full membership of the EU is highly sensitive and controversial both politically and economically. An obvious peril for Turkey is regarding EU membership as a panacea for all its domestic ills. One has to recall that Turkey already has a functioning customs union with the EU since 1995, hence a number of trade gains are already in place. In any case, Turkey may be welcome to the EU, but it has to make its European identity and credentials right and clear.

The negotiation and preparation process may easily last about 15 years (if there are no political interruptions in Turkey). Apart from the Copenhagen criteria for EU entry, there are also others. Turkey is a special, indeed a very special EuroOriental country. The obvious conditions are the following:

- Genocide: Highest-level German statesmen and politicians have explicitly and officially stated their apologises for the genocide committed during the Second World War. The country is still paying compensation to victims. As such, Germany has passed through the moral catharsis (Vergangenheitsbewältigung) and is accepted in the family of countries that share common European values. Turkey will be asked do the same. The genocide committed by Turkey against the Armenians in 1915 left 1.5 million Armenians dead. Turkey will be asked to come to terms with this (as the Germans have). An international commission on this issue might be a good starting point.

- Expansionism: Germany relinquished the expansionist Nazi-type pan-German ideas that are very dangerous for peace. This is most obvious and important in relations with Poland(Germany's eastern border). Turkey's statesmen, politicians and government institutions must clearly and publicly renounce the pan- Turkish ideas asserted even by the latest generation of its statesmen such as Suleiman Demirel and Turgut Ozal about a Turkey 'from the Chinese Wall until the Adriatic sea'. Such ambitions, dangerous for peace, introduce concerns and fears about the reestabilshment of the Ottoman Empire (1350-1918). Austrians still have a strong collective memory about the sufferings during the Turkish sieges of Vienna (15291683 ) and fear that this may be repeated. Many of them wonder if the 1683 victory over the Ottoman Empire was in vain. There are also constant Turkish claims and provocations regarding Greek territory ${ }^{1}$.

${ }^{1}$ One immediately thinks of the islands of lmia and Gavdos. 
Turkish speaking countries: Following the dissolution of the former Soviet Union, Azerbaijan, Kazakhstan, Turkmenistan, Kyrgyzstan and Uzbekistan emerged as independent Turkish-speaking states. Would Turkey also bring into the EU these countries or, at least, their Turkish-speaking citizens? There are also concerns and fears in the EU about the large-scale intrusion of Moslems into Europe and a 'clash of civillsations'.

- Cyprus: Turkey must withdraw all occupation forces from this EU member country. Cyprus must be recognised in its entirety. In addition, illegally seized property in Cyprus must be returned to original owners.

- Kurds: Turkey must improve the treatment of its Kurdish minority that is about 12 to 15 million strong. Calls for regionalisation and autonomy are quite strong.

- Frontier control: Turkey has a long frontier with countries such as Lebanon, Syria, Iraq and Iran. It is quite hard, demanding and costly to police it effectively. Thrkey has to demonstrate that it can apply, keep and implement EU standards regarding this issue.

These are all tough and important issues that must be deal with. In additions, by 2015, Turkey would be the most populous EU state. It would have the biggest single voting power in the EU. This would have an enormous consequence on the voting process and operation of the entire EU. The choice of whether to let Turkey in or not is neither simple nor easy. Even the European Commission has publicly revealed division on the issue. Frits Bolkestein (Dutch) is against the entry of Turkey for historical, political and religious reasons. Franz Fischler (Austrian) is opposed to entry not only because of the lack of 'long-tern secular and democratic credentials' but also because the financial cost of applying only thd CAP in Turkey would not be tenable. It would cost the EU $€ 11.5$ billion a year. However, Chris Patten (British) is positive about Turkish entry and argues in favour of an increase in EU farm and structural spending. ${ }^{2}$

It is complex even now to create a common and coherent EU foreign and defence policy. Given the political and military weight of Turkey, this would become unconceivable in an enlarged EU. The EU might be easily transformed into an impressively large free trade area with certain elements of policy coordination. Britian may argue that this is not a bad idea at all. One of the possible options is to

\footnotetext{
${ }^{2}$ Bulletin Quotidien Europe, 8 September 2004, p. 4 and 16 September 2004, p. 3; Q. Peel, 'The case for
} letting Turkey', The Financial Time, 16 September 2004, p. 21; Enlargement Weekly, 21 September 2004. 
offer Turkey a 'special partnership status', rather than full membership.

No real and wide public debate has yet taken place about the entry of Turkey. EU citizens (and voters) need to know what benefits Turkish entry would bring them. If the entry of Turkey is presented by the elite as a done deal without wide public debate and consultation with the people (voters), their resistance and revenge may shatter the project later. ${ }^{3}$

In spite of public statements by various governments tha Turkey is welcome into the EU, polls reveal that the EU public shows serious discomfort about letting in such a big, poor and culturally and religiously different country into the EU club. ${ }^{4}$ If Turkey is in the EU, then it would be hard to say 'no' to countries such as Armenia, Azerbaijan, Georgia, Moldova and, of course, to Russia, Ukraine and Belarus.

Received 15 April 2003, Accepted 29 September 2003

\section{References}

Baldone, S., F. Sdogati and L. Tajoli (2002). Moving to central-eastern Europe: fragmentation of production and competitiveness of the European textile and apparel industry, Rivista di Politica Economica, pp. 208-281.

Baldwin, R. (1995). The eastern enlargement of the European Union, European Economic Review, pp. 474-481.

Bauer, P. (1998). Eastward enlargement benefits and costs of EU entry for the transition countries, Intereconomics, January/February, pp. 11-19.

Braunerhjelm, P., R. Faini, V. Norman, F. Ruane and P. Seabright (2000). Integration and the Regions of Europe: How the Right Policies Can Prevent Polarization. London: CEPR.

Brenton, P. and F. di Mauro (1998). Is there any potential in trade in sensitive industrial products between the CEECs and the EU?, World Economy, pp. 285-304.

Burda, M. (1998). The consequences of EU enlargement for central and east European labour markets, CEPR Discussion Paper, No. 1881.

CEPR (1992). Is Bigger Better? The Economics of EC Enlargement. London: Centre for

\footnotetext{
${ }^{3}$ This may happen even earlier on an unrelated issue. There will be quite a few national referendums about the ratification of the Constitutional Treaty.

${ }^{4}$ Austria, Cyprus and Greece are the most obvious examples. The Scandinavian countries attach great weight to the human right record. In addition, Ljubljana (Slovenia) is the only EU capital without a mosque.
} 
Economic Policy Research.

Davenport, M. (1995). Fostering integration of countries in transition in central and eastern Europe in the world economy and the implications for the developing countries, UNCTAD, ITD/7, 31 October 1995.

de Grauwe, P. (2002). The challenge of the enlargement of the Euroland, Paper presented at the conference EU Enlargement: Endgame Economic Issues, Jean Monnet European Centre of Excellence, University of Genoa, 15 November 2002.

de Melo, J., F. Miguet and T. Müller (2002). The political economy of migration and EU enlargement: lessons from Switzerland, University of Geneva, mimeo.

Deutscher Bundestag (1999). Jahresbericht 1999 der Bundesregierung zun Stand der Deutschen Einheit, Drucksache 14/1825, 10 Oktober 1999.

Economic Commission for Europe (1996). Economic Bulletin for Europe. New York: United Nations.

Economic Commission for Europe (1997). Economic Survey of Europe in 1996-1997. New York: United Nations.

Economic Commission for Europe (1998). Economic Survey of Europe 1998 No.3. New York: United Nations.

Economic Commission for Europe (2000). Economic Survey of Europe 2000 No.1. New York: United Nations.

Economic Commission for Europe (2002). Economic Survey of Europe 2002 No.1. New York: United Nations.

Economic Commission for Europe (2003). Economic Survey of Europe 2003 No.1. New York: United Nations.

European Commission (1997). Agenda 2000 for a Stronger and Wider Union. Luxembourg: European Communities.

European Commission (2002). Towards the Enlarged Union: Strategy Paper and Report of the European Commission on the Progress towards Accession by Each of the Candidate Countries. Brussels, 9 October 2002, COM(2002) 700 final.

Euro Papers (2001). The economic impact of enlargement, Enlargement Papers No. 4.

European Economy (1997a). The CAP and enlargement, No. 2.

European Economy (1997b). Towards a Common Agricultural and Rural Policy for Europe, No. 5.

European Economy (2003). Structural features of economic integration in an enlarged Europe: patterns of catching-up and industrial specialisation, Economic Papers No. 181.

European Economy (2003). Main results of the April 2003 fiscal notifications presented by the candidate countries, Enlargement Papers No. 17.

European Economy (2003). Key structural challenges in the acceding countries: The integration of the acceding countries into the Communitys economic policy coordination processes, Occasional Papers No. 4.

European Economy (2003). Economic forecasts for the candidate countries Spring 2003, Enlargement Papers No. 15. 
Fisher, S., R. Sahay and C. Végh (1998). How far is eastern Europe from Brussels?, IMF Working Paper, WP/98/53.

Heinemann, F. (2002). The political economy of eastern enlargement, Rivista di Politica Economica, pp. 359-383.

Hertel, T., M. Brockmeier and P. Swaminathan (1997). Sectoral and economy-wide analysis of integrating central and eastern European countries into the EU: implications of alternative strategies, European Review of Agricultural Economics, pp. 359386.

Jovanović, M. (1997). European Economic Integration: Limits and Prospects. London: Routledge.

Jovanović, M. (1997a). Probing leviathan: the eastern enlargement of the European Union, European Review, pp. 353-370.

Jovanović, M. (1998). International Economic Integration: Limits and Prospects. London: Routledge.

Jovanović, M. (1998a). Does eastern enlargement mean the end of the European Union?, International Relations, pp. 23-39.

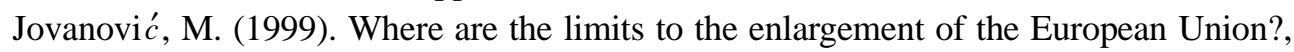
Journal of Economic Integration, pp. 467-496.

Jovanović, M. (2000). Eastern enlargement of the European Union: sour grapes or sweet lemon?, Economia Internazionale, pp. 507-536.

Jovanović, M. (2001). Geography of Production and Economic Integration. London: Routledge.

Jovanović, M. (2003). Local vs. global location of firms and industries, Journal of Economic Integration, pp.60 104.

Jovanović, M. (2005). The Economics of European Integration. Cheltenham: Edward Elgar.

Keuschnigg, C. and W Kohler, (2000). Eastern enlargement of the EU: a dynamic general equilibrium perspective, in Using Dynamic General Equilibrium Models for Policy Analysis (eds G. Harrison, S. Hougard Jensen, L. Haagen Pedersen and T. Rutherford), Amsterdam: Elsevier, pp. 119-170.

Krugman, P. (1998). The Accidental Theorist. New York: Norton.

Midelfart-Knarvik, K., H. Overman, S. Redding and A. Venables (2000). The location of European industry, Economic Papers, No. 142, European Commission.

Nicolaides, P. (1999). The economics of enlarging the European Union: policy reform versus transfers, Intereconomics, January/February, pp. 3-9.

OECD (2003). Trends in International Migration (SOPEMI 2002). Paris : OECD. p. 85.

Praussello, F. (2002). The stability of EMU in the aftermath of the EU eastwards enlargement, Paper presented at the conference EU Enlargement: Endgame Economic Issues, Jean Monnet European Centre of Excellence, University of Genoa, 15 November 2002.

Puga, D. and A. Venables (1997). Preferential trading arrangements and industrial location, Journal of International Economics, pp. 347-368. 
van Brabant, J. (1996). Remaking Europe - the accession of transition economies, Economia Internazionale, pp. 507-531.

van Brabant (2001). EU widening and deepening are these goals reconcilable?, Most, pp. 113-141.

Venables, A. (1996). Localization of industry and trade performance, Oxford Review of Economic Policy, pp. 52-60. 